ELORE (ISSN 1456-3010), vol. 18 - 2/2011.

Julkaisija: Suomen Kansantietouden Tutkijain Seura ry.

[http://www.elore.fi/arkisto/2_11/stark.pdf]

\title{
AJANKOHTAISTA
}

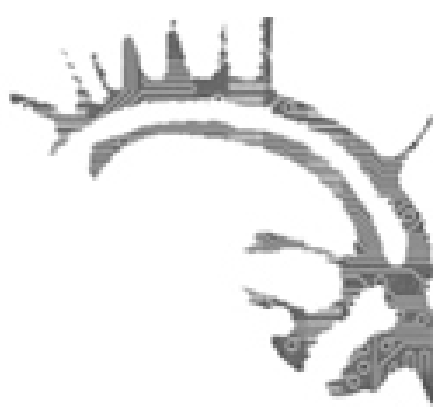

\section{KULTTUURINEN TIETO JA KÖYHYYDEN KULTTUURI}

\section{Eija Stark}

Lectio praecursoria Helsingin yliopistossa 14.5.2011

Tällä hetkellä suomalainen yhteiskunta on vauraampi kuin koskaan aiemmin ja myös asukaslukuun suhteutettuna maailman rikkaimpien joukossa. Tästä huolimatta kollektiivista omakuvaamme leimaa ajatus siitä, että rikkaus ei ole ikuista ja hyvinvoinnin keskelläkin niukkuuden kulttuuria ei saisi unohtaa. Omakuvaamme leimaa myös kansallinen itsepärjäämisen eetos ja sitä odotamme myös muilta.

Suomalaisten historiatietoisuuteen on kerrostunut useita kansallisesti merkittäväksi koettuja vaiheita. Yksi tällainen on köyhyys ja elämän ankaruus, josta jo Zacharias Topelius kirjoitti Maamme kirjassa seuraavasti: "Muun maailman silmissä meidän maamme on köyhä ja kaukainen. Meillä ei ole suuria ylpeilemisen aiheita. Meidän tulee olla nöyriä, ahkeria, säästäväisiä ja oppivaisia, ettei tulisi pakkoa turvautua muiden armoihin. Mutta se ei kiellä meitä rakastamasta maatamme enemmän kuin mitään muuta maata maailmassa" (Topelius 1985 [1875], 29).

Alhainen elintaso oli Suomessa vielä pitkään historiallinen realiteetti, joka heijastui myös ihmisen sanalliseen kulttuuriin: sekä korkeakulttuurin kirjallisiin tuotoksiin että kansankulttuurin ilmaisumuotoihin kuten satuihin, epiikkaan ja ihmisten henkilökohtaiseen muistelukerrontaan. Suomessa useampikin tasavallan presidentti, poliitikko, korkea virkamies tai suuren yrityksen johtaja on kertonut julkisuudessa entisajan köyhyyden kulttuurista ja sen ominaisista piirteistä osana omaa identiteettiään. Tyypillisiä teemoja tällaisessa köyhyyspuheessa ovat muun muassa syntyminen monilapsiseen perheeseen, usein maaseudulle, kunnanavun saaminen vaatteiden muodossa ja varhain aloitettu työnteko. Ei ole harhaanjohtavaa sanoa, että köyhyyttä on aina ilmennetty myös viestinnällisinä tekoina, suullisena ja kirjallisena traditiona, jonka alkujuuret ovat jossain historian hämärässä, mutta joka aikalaisille näyttäytyy yhä käyttökelpoiselta puheenaiheelta tilanteesta riippuen. Puute ja niukkuus ovat täällä tuottaneet sukupolvien ajan tapoja havainnoida ja kategorisoida maailmaa, toisin sanoen kulttuurista tietoa, jota kerrotaan eteenpäin yhä uudestaan ja uusissa yhteyksissä. 
Eija Stark : Kulttuurinen tieto ja köyhyyden kulttuuri

\section{KULTTUURI ON TIETÄMISTÄ}

Kerronnassa ilmaistu historiallinen tietoisuus ja identiteetti ovat vuoropuhelua menneen kanssa. Tällaista henkistä kansankulttuuria ja suullista perinnettä kutsutaan folkloreksi. Nimitys tulee englannin sanoista folk, "kansa" ja lore, "perimätieto". Suppeimmillaan folklore voidaan käsittää kirjoittamattomaksi kirjallisuudeksi, kansan sanataiteeksi, johon kuuluvat kansanrunous ja kansankertomukset. Laajemmin käsitteellä viitataan kaikkeen kansanomaiseen kulttuuriin, johon kuuluvat perinnäiset uskomukset ja käsitykset tai esimerkiksi tapa laittaa ruokaa. Myös asenteet ja käsitykset voivat olla folklorea, esi-isiltä -ja äideiltä perittyä tietoa. Asenteet, tavat, uskomukset ja normit edustavat kaikki epämuodollisia instituutioita eli ne ovat sosiaalisen järjestyksen ja yhteistyön rakenteita ja mekanismeja, jotka ohjaavat ihmisten käyttäytymistä. Kertoessaan esimerkiksi köyhyydestä joko kansankertomuksina, osana elämäkertaansa tai sananlaskuina ihmiset ovat välittäneet eteenpäin käsityksiään olemassa olevasta todellisuudesta ja siihen liittyvistä normeista.

Ihmisen kulttuurikäyttäytymisellä on siis myös sanallinen ulottuvuutensa. Kielellä esimerkiksi kerrotaan tapahtumista, toiveista, peloista ja pyrkimyksistä. Kielellä myös ilmaistaan, millaisia aistimuksia, tuntemuksia ja tunteita koetaan, toivotaan tai pelätään. Vaikka kaikki ajatukset eivät ole kielellisiä eli ihmiset eivät tuo niitä esiin, auttaa kieli ihmistä pohtimaan ja järkeilemään asioita, vaikkei hän niistä muille koskaan kertoisikaan. Kieli onkin kiinnostava kognition eli ihmisen tietokyvyn osa, koska ihminen puhuu siitä, mitä hän näkee, kuulee ja tuntee. Ihminen puhuu myös ihmissuhteista ja monesta muusta asiasta, mitä hänellä on mielessään, vaikkei hän sitä tietoisesti ymmärtäisikään. Kielessä ei ole sanaa tai muuta ilmausta jokaiselle tunteelle, jokaiselle hajulle tai kaikentyyppisille ihmissuhteille. Kieli pystyy välittämään jotain ihmisen sisäisestä elämästä ja siitä, kuinka yksilöt ymmärtävät ympäröivän maailman. (Nikanne 2003, 78-79.)

Mutta kieli ja sen ilmaisemat viestit on aina asetettava johonkin kontekstiin, reaalimaailmaan. Satu Apon mukaan ennen kuin voimme tehdä johtopäätöksiä ympäröivästä maailmasta ja ihmisten käsityksistä tuosta maailmasta, tarvitsemme tietoa tutkimuskohteena olevien ihmisyhteisöjen elämän perusrakenteista. Tällaisia ovat esimerkiksi taloudelliset ja sosiaaliset järjestelmät, elinkeinot, lainsäädäntö tai esimerkiksi sukupuolten välinen työnjako. (Apo 1984, 6-8.) Yhteiskuntahistoriallinen kontekstualisointi, toisin sanoen suullisen perinteen tulkitseminen kulttuurituotteena osana jotakin historiallista ajanjaksoa ja yhteiskuntarakennetta onkin avain ymmärrykseemme vanhaan suulliseen perinteeseen ja sen aikalaismerkityksiin.

Vertaillessaan suomalaisia ja Namibian ovambolaista kansanperinnettä, Matti Kuusi on todennut, että suomalaisten mahdollisuudet ymmärtää namibialaisten käsityksiä samalla tavalla kuin namibialainen, riippuu ennen kaikkea heidän elämänpiiriensä eroista (Kuusi 1994, 156-157). Näin on myös esimerkiksi sananlaskujen kohdalla. Kuusi tähdentää Edvard Westermarckia mukaillen, miten kansa tuskin missään omaksuu vierasta sananlaskua, ellei se jossain määrin ole sen mielen- ja elämänlaadun mukainen. (Kuusi 1954, 71.) 
Sananlasku "minä herra, sinä herra, kumpi meistä kontin kantaa" tunnetaan Itämeren alueella asuvien kansojen keskuudessa. Intialainen ja pakistanilainen sen sijaan kysyvät: "Jos minä olen kuningatar ja sinä olet kuningatar, kuka sitten kantaa vedet kaivosta?’' Kuten voi havaita, nämä sanonnat polveutuvat samasta, etäisestä alkumuodosta, mutta kieli- ja kansatieteellisten rajojen yli kulkeutuessaan tämä sosiaalista marssijärjestystä kuvaava sananlasku on sopeutunut uudelleen. Ihmiset ovat muokanneet sanontaa omaan elinympäristöönsä ja arkirutiineihinsa sopivammaksi. Se on siis kotoperäistetty kieliasultaan riippuen missä päin maailmaa ollaan, itse ideaa kuitenkaan muuntamatta. Matti Kuusen sanoin "eläin-, kasvi- ja kansatieteellinen miljöö painaa parrelleen” (Kuusi 1954, 59). Kun Suomessa lähdetään sutta pakoon, tulee karhu vastaan, niin Kiinassa päädytään suden suusta tiikerin hampaisiin ja Intiassa skorpionia paetessa joudutaankin myrkkykäärmeen kitaan.

\section{KÖYHYYDEN KULTTUUURI PUHEESSA}

Ihan samoin kuin monissa sananlaskuissa kautta maailman, köyhyydessä elävien ihmisten arjessa eri puolilla maailmaa ja eri historian aikoina on samoja piirteitä. Köyhys sen kurjimmassa muodossa on puutetta puhtaasta juomavedestä, huonoa ravintoa tai suoranaista nälkää, surkeita asuinoloja, olematonta hygieniaa, terveydenhuollon puutetta ja lukutaidottomuutta.

Antropologi Oscar Lewisin nimeämään köyhyyden kulttuurïn kuuluu myös sosiaalisia ja psykologisia ominaispiirteitä kuten asuminen ahtaissa mökeissä, oman rauhan puuttuminen, turvautuminen väkivaltaan riitoja ratkaistaessa ja väkivallan yleisyys lasten kasvatuksessa, ydinperheen vallitsevuus ja suuntaus kohti äitikeskeisiä perheitä. Tämän lisäksi köyhien yhteisöissä orientoituminen nykyhetkeen on vahvaa, minkä käänteinen puoli on kyvyttömyys suunnitella tulevaisuutta. (Lewis 1961, 22-23.)

Tästä huolimatta kieli-, kulttuuri- ja etnisyysrajojen ylittävät köyhyydelle yhteiset piirteet eivät tuota yhteneväisiä kulttuureja, yhteiskuntia tai historian kulkuja. Kysymys on myös eri kansojen elämänkatsomuksen ja normijärjestelmien poikkeavuuksista. Köyhyyden kulttuurissa on universaaleja piirteitä, mutta myös eroja riippuen siitä, kuinka vauras ympäröivä yhteiskunta on tai millainen on esimerkiksi naisen asema työmarkkinoilla. Myös historian kulku muuttaa köyhyyden kulttuureja: ryysyistä rikkauksiin tuottaa uudenlaisia näkökulmia toimeentulokamppailuihin kuin se, että ihminen syntyy ja kuolee köyhänä. Kuten Anna-Leena Siikala on todennut, folkloressa ei ole kysymys irrallisten kulttuuri-ilmiöiden satunnaisesta kokoelmasta, vaan se tulee nähdä osana suullisen perinteen kokonaisuuksia, sosiaalisia rakenteita ja niiden historiallisia vaiheita. Siikalalle kulttuuri on jatkuvaa liikettä ja siten muuttuva systeemi, jossa jotkin ilmiöt ovat pitkäikäisiä, hyvinkin vanhoja ja jotkut uusia. (Siikala 1992, 28-35; Koski 2007 , 6.) Eri kulttuureissa tai erilaisissa kulttuurisissa tilanteissa samankaltaiset ilmiöt, kuten köyhyys, voivatkin saada erilaisia merkityksiä.

Olen tutkimuksessani tarkastellut suomalaista köyhyyden kulttuuria elämäkerroissa ja sananlaskuissa ilmaistujen käsitysten, ideoiden ja arvojen kautta. Näitä olen suhteuttanut osaksi tietämykseemme etnografisesta ja historiallisesta todellisuudesta. Vielä 
1900-luvun alussa köyhyys kuului kiinteänä osana monen suomalaisen päivittäiseen arkeen läpi elämän: köyhänä synnyttiin ja köyhänä kuoltiin. Folkloristiikassa on jo pitkään tiedostettu se, miten eri kertomuslajien kesken vallitsee viestinnällinen työjako (Honko 1988, 99). Sananlaskut välittävät köyhyydestä eri puolia kuin esimerkiksi ihmisten omaelämäkerrat. Köyhyyttä käsittelevät kerronnan lajit eivät tarkalleen ottaen kerro siitä, mitä entisajan köyhyys oli vaan sen, mitä kertojat ovat pitäneet köyhälle yksilölle mahdollisena, tyypillisenä, toivottavana tai yleisenä kehityksenä hänen elämänkulussaan.

\section{JAKO KAHTEEN}

Suomessa yhteiskunnalliset ja kulttuuriset erot syntyivät omaisuuden mukaan (Haapala 1995, 99). Näkemykset ja arviot toisista ihmisistä liittyivätkin kiinteästi omaisuuteen: rahan, karjan, tilusten ja tavaroiden määrään. Suomalaisessa kulttuurissa on ollut jako kahteen: on ollut herroja ja on ollut rahvasta. Herrat ovat olleet rikkaita ja köyhät rahvasta. Vaikka köyhyys ja rikkaus ovat olleet ulospäin näkyviä, fyysisiä ilmiöitä, herran ja rahvaan jaottelua on ilmennetty myös sanallisessa viestinnässä - esimerkiksi sananlaskujen ja kansansatujen avulla - joiden yksi keskeinen aihelma on ollut herrojen ylempi asema ja erioikeudet.

Herroilla meni köyhälistön näkökulmasta hyvin ja herrojen elämä vaikutti työtätekevästä rahvaasta melko helpolta: "On herran päivät ja koiran vaivat!" Tästä huolimatta paremman väen, kuten myös herroja kansanomaisessa kielenkäytössä kutsuttiin, ylivoima ja valta kuitenkin kyseenalaistettiin. Herratkin nähtiin tavallisina kuolevaisina, joilla oli omat, inhimilliset heikkoutensa: "Hengähtää ne herrojenkin hevoset pitkän matkan juostuansa." Matti Kuusen mukaan oppineiston korostaessa sääty-yhteiskunnassa herran ja rahvaan syvää vastakohtaisuutta, "tuntematon kansanajattelija" esitti oman vastakkaisen näkemyksensä, johon kuului käsitys kaikkien ihmisolentojen peruslaadun ja perusoikeuksien samuudesta (Kuusi 1954, 88). Siinä katsantokannassa herrojen mahtavuus rajautui ainoastaan tämänpuoliseen: "Herra se on herrallakin, köyhälläki Jumala."

Myös rahvas saattoi puhua itsestään herrana. Tällöin herralla viitattiin yksilölliseen itsemääräämisoikeuteen ja vapauteen. Jos elämässä sai aineellista tai sosiaalista onnea osakseen, antoi se aihetta verrata asemaansa herran asemaan: "Herroiksi eletään vaikka lopun ikää kerjättäis." Herra-puhe onkin toisinaan vertauskuva johonkin onnekkaaseen sattumaan, tilanteeseen tai olosuhteeseen. Herruutta on siis tavallisesta arjesta poikkeava, usein materiaalisesti värittynyt positiivinen kokemus. Tämän vuoksi herruus ja herrat eivät olleet pelkästään negatiivisia asioita. Koulutuksen ja vaurauden laajentuessa 1900-luvulla herroihin samastumiselle tuli realistinen pohja: hetkittäisistä herraskaisista kokemuksista kuten hevoskyydillä matkustamisesta, kaupungissa vierailusta tai leivoksen syömisestä saivat iloita myös maaseudun työläiset ja palkollisväki.

Herran ja rahvaan eroa ilmennettiin tapakulttuurilla ja ulkoisin merkein: herran ja rahvaan erotti toisistaan pukeutuminen ja käytöstavat, toisinaan myös kieli. Suomessa vauraus ja omistaminen ovatkin olleet ihmisiä sosiaalisesti luokitteleva tekijä. Köyhät kuuluivat vähiten arvostettujen henkilöiden joukkoon omassa yhteisössään. Kun 
Eija Stark : Kulttuurinen tieto ja köyhyyden kulttuuri

hyvinvointi lisääntyi ja koulutusmahdollisuudet laajenivat, aiemmat taloudellisesta epätasa-arvosta johtuneet kategoriat alkoivat hajota. Hyvinvoinnin lisääntyminen yksilön elämänkulun aikana ei kuitenkaan poistanut mieleen juurtuneita käsityksiä.

Sosiaalisia raja-aitoja koeteltiin myös avioliittoja solmittaessa. Hyvän puolison lisäksi oli kysymys toimeentulon vakiinnuttamisesta. Köyhyyden kerrotaan vaikuttaneen siihen, millaista puolisoa on etsitty aviokumppaniksi. Sananlaskun mukaan: "Rikkaat rikkaita naivat, piiat, rengit toisiansa." Useista elinkeinoista koostuva toimeentulo tarvitsi tekijäänsä. Mökeissä ja taloissa tarvittiin työvoimaa ja traditionaalisen työjärjestyksen sisäistäneitä suorittajia, jolloin puolisonvalintaan haluttiin vaikuttaa aktiivisesti. Naima-asioihin pyrittiin tarpeen tullen puuttumaan, jos nuori oli valitsemassa värin. Avioliiton solmiminen oli - ei vain herrasväen - vaan myös köyhän rahvaan keskuudessa merkittävä sosiaalinen ja taloudellinen siirto.

Aineellisesti niukka elämä liittyy aina toimeentulon ja työn kysymyksiin, joka suomalaisessa kulttuurissa konkretisoituu fyysisen työn arvostamisena. Sananlasku: 'Työstä miestä arvostellaan, ei suurista sanoista" kiteyttää työn antaman kunnian. Liiallista raatamista vastaan oli kuitenkin kohtuullista työntekoa korostava etiikka. Ihmisten empiiriset havainnot kyseenalaistivat henkihieveriin asti yltävän työn mielekkyyden: "Ennen makaa itsensä köyhäksi kuin tekee köyhäksi."

Työnteon yhtenä suomalaisena erityispiirteenä on have omilleen pääsemisestä oman talon tai asunnon hankkimisella. Talonpoikainen omistaminen oli pitkään tilattomien haaveena ja kun maareformien seurauksena pientiloja ryhdyttiin 1900-luvulla perustamaan, joutuivat entiset tilattomat raivaamaan tilansa ja rakentamaan asuntonsa usein alusta pitäen. Köyhyyden kulttuuriin kuuluva raatamisen eetos ja työkultti liittyvät tähän kollektiiviseksi laajentuneeseen kokemukseen: itsenäisyyden lunastamiseen kului vuosia työntäyteistä elämää.

\section{JaTKUVUUS}

Suomessa maalaisköyhyyden näkyvimmät muodot väistyivät varsin myöhään, vasta oikeastaan 1960-luvulla ja joiltain osin jopa tätäkin myöhemmin. Monelle 1920- ja 1930-luvulla syntyneelle suomalaiselle agraarista ja lähes staattisesta sääty-yhteiskunnasta on tullut heidän elinaikanaan teollistunut ja vaurastunut yhteiskunta. Suomessa yhteiskunnalliseen eliittiin on noussut paljon köyhistä oloista lähteneitä. He korostavat hyvinvoinnin merkitystä, mutta samalla puheessa on niukkuuden ja vaatimattomuuden korostus. Topeliuksen sanat: "On vaarallista, jos kansa hyvinä aikoina totuttaa itsensä ylellisyyteen, jota se huonoina aikoina ei enää voi maksaa" (1985 [1875], 548) näyttääkin Suomessa sisäistetyn varsin tiukasti.

Suomalaisen köyhyyspuheen tarkastelu ja sen tulkitseminen kulttuuriseksi tiedoksi, jolla on jatkuvuutensa, auttaakin laajentamaan ja syventämään kuvaamme siitä, millaisia jatkuvuuksia ja katkoksia sisältyy yhteiskunnassa vallitseviin ajattelutapoihin ja -rakenteisiin. Folkloristiikka tieteenalana ei siten ole kadotettua kansallista eheyttä tai eksoottista menneisyyttä kuvaava kuriositeetti, vaan se avulla on mahdollista ymmärtää syvällisesti jotain myös tämän päivän maailmasta. 
Eija Stark : Kulttuurinen tieto ja köyhyyden kulttuuri

Stark, Eija 2011: Köybyyden perintö. Tutkimus kulttuurisen tiedon sisällöistä ja jatkununksista suomalaisissa elämäkerta- ja sananlaskuaineistoissa. Helsinki: SKS.

\section{KirjallisuUs}

APO, SATU 1984: Kansankulttuurimme kaksi kuvaa - Kotiseutu 1/1984.

HAAPALA, PERTTI 1995: Kun ybteiskunta hajosi. Suomi 1914-1920. Helsinki: Kleio ja Nykypäivä.

HONKO, LAURI 1988: Perinnelajiteoria - Sananjalka 20.

KOSKI, KAARINA 2007: Folkloristi ja vapaa sielu. Haastattelussa Anna-Leena Siikala - Elore 1/2007.

KUUSI, MATTI 1954: Sananlaskut ja puheenparret. Helsinki: SKS.

KUUSI, MATTI 1994: Mind and Form in Folklore. Selected articles. Helsinki: SKS.

LEWIS, OSCAR 1961: Sánchezin lapset. Helsinki - Porvoo: WSOY.

NIKANNE, URPO 2003: Kieli ja ihminen - Virittäjä 1 / 2003.

SIIKALA, ANNA-LEENA 1992: Suomalainen shamanismi-mielikuvien historiaa. Helsinki: SKS.

TOPELIUS, ZACHARIAS 1985 [1875]: Maamme kirja. Porvoo - Helsinki - Juva: Werner Söderström Osakeyhtiö.

Filosofian tohtori Eija Stark on tutkijana Helsingin yliopiston Filosofian, historian, kulttuurin ja taiteiden tutkimuksen laitoksessa, folkloristiikan oppiaineessa. 